\title{
A STUDY OF COMPARISON ON KNOWLEDGE AND MISCONCEPTIONS ABOUT HIVIAIDS AMONG STUDENTS IN A PRIVATE UNIVERSITY IN MALAYSIA
}

\author{
Nazmul MHM¹, Fazlul MKK², Deepthi $\mathrm{S}^{1}$, Farzana $\mathrm{Y}^{3}$, Munirah $\mathrm{B}^{4}$, Najnin $\mathrm{A}^{5}$ and Srikumar $\mathrm{C}^{1}$ \\ ${ }^{1}$ Centre of Research excellence, Graduate School of Medicine, Perdana University, Jalan MAEPS Perdana, Serdang 43400, \\ Selangor, Malaysia. \\ ${ }^{2}$ Faculty of Industrial Sciences and Technology, Universiti Malaysia Pahang, Gambang, 26300 Pahang, Malaysia. \\ ${ }^{3}$ Faculty of Science, Lincoln University, 12-18, Jalan SS6/12, Off Jalan Perbandaran, 47301 Petaling Jaya, Selangor Malaysia. \\ ${ }^{4}$ Faculty of Medicine, SEGi University, Kota Damansara, Petaling Jaya, 47810 Selangor, Malaysia. \\ 5 Jeffrey Cheah School of Medicine and Health Sciences, Monash University, No.8, Jalan Masjid Abu Bakar, 80100 Johor \\ Bahru, Malaysia.
}

Corresponding address: Mohammad Nazmul Hasan Maziz

Email: poorpiku@yahoo.com

\begin{abstract}
This descriptive cross-sectional study is aimed at studying the comparison on knowledge and misconceptions about HIV/AIDS among the Malaysian undergraduate students at SEGi University, Kota Damansara, Malaysia. Data was collected from a stratified random sample of 180 students using a validated questionnaire survey which included a socio-demographics section and four sub-sections of 36 questions which assessed the general knowledge, general public perceptions, the respondent's views on the measures to prevent the disease and misconceptions related to the disease. The data were analysed by using the SPSS software, and Chi-square test was used to find the p-value for each of the questions. The average mean score assessing the knowledge of the Malaysian students in SEGi was 81.48\%, where the Health Science students scored $44.31 \%$ with a standard deviation of 0.015 and the Non-Health Science students scored $37.17 \%$ with a standard deviation of 0.036 . When comparing each question using the Chi-square test, most of the answers of the Health Science students and Non-Health Science students showed a significant difference where the $p$-value was $<0.05$. From the results of this study it is clear that the Health Science students had better knowledge and fewer misconceptions about HIVIAIDS than the Non-Health Science students. Thus, more emphasis should be directed toward raising awareness and eliminating misconceptions among the Non-Health Science students.
\end{abstract}

Keywords: Misconception, HIV/AIDS, private university, Malaysia.

\section{INTRODUCTION}

Today HIV is one of the largest epidemics in the world. The main aim of this research was to compare the knowledge and misconceptions of the Health Science students and Non-Health Science students regarding HIV/AIDS in SEGi University which is located in Kota Damansara, Selangor, Malaysia.

HIV/AIDS is not something one should take lightly. With only 5 percent of the Eastern and Southern African, it is home to half of the world's population living with HIV. In recent decades, HIV/AIDS has been working its magic up into society, spreading like an unstoppable cancer, almost to the point of it being immortal ${ }^{1}$. Due to this fact alone, students of the community must have the right and ample knowledge regarding this matter, aside from having a positive attitude towards both the illness and the victims of this very disease. Misconceptions of HIV/AIDS when encountered throughout one's life line (career) can lead to serious mishaps. In other words, they would not know how to deal with the problem professionally ${ }^{1}$.

Due to lack of adequate information, youths are more exposed to infection as they engage in risky sexual practices. It is of utter importance that both Health Science and Non- Health Science undergrads are equipped with the knowledge of HIV/AIDS. This is because having the knowledge of HIV/AIDS would benefit oneself to brace for what is coming if plagued by the dreaded malady ${ }^{2}$.

Having good general public perception towards the possible causes of HIV infection serves as a tool to create better health care programs encouraging empathy towards victims ${ }^{2}$. However, these studies have been limited to compare integrated knowledge and misconceptions of the Health Science and NonHealth Science students. Few studies have examined potential differences in knowledge, risk perception and misconception towards HIV/AIDS. This study was conducted among the Health Science and Non-Health Science students because University 
students are amongst population in the age groups with the highest probability of acquiring HIV/AIDS as they are not aware of HIV risks ${ }^{3}$.

The first HIV case in Malaysia was detected in 1986. Since then, the cumulative number of HIV infections up to June 2007 shows an amount of 78,784 cases. The rapid increase of HIV/AIDS among young people is an alarming fact ${ }^{4}$. As a moderate Islamic country, Malaysia has majority of Muslim Malays and other ethnicities such as Chinese and Indian living together with religious freedom. Topics such as sex and sexually transmitted infections (STIs) are considered taboo and sensitive, and usually are not discussed openly. Although Malaysians are mostly conservative and strictly hold on to their traditional values, the younger generation engage in unprotected sexual intercourse $e^{4}$. The cumulative number of HIV cases in Malaysia went up to 101,672 cases by the end of $2013^{5}$.

In Malaysia, talks and awareness programs about HIV/AIDS are held at secondary schools regularly. However, there are new cases of HIV/AIDS arising among people every year. This could be caused by low level of knowledge regarding HIV/AIDS. This shows that the awareness programs held at school levels alone is not enough to prevent this disease from spreading. Thus, the knowledge and misconceptions about this disease among university students should also be assessed. Health Science students have a better exposure to gaining knowledge about this disease since it is a part of their curriculum whereas it is not the case for NonHealth Science students. Thus, this study is carried out to compare knowledge and misconceptions among the Health Science students and Non-Health Science students about HIV/AIDS in SEGi University, Kota Damansara, Malaysia.

\section{METHODS}

\section{Study design}

This is a descriptive, cross sectional study that was conducted via a self-administered questionnaire among Health Science and Non-Health Science students in SEGi University, which is a private university located in Kota Damansara, Malaysia.

\section{Study population}

The study population includes undergraduate students from SEGi University, Kota Damansara. All the students were informed about the study design. Those who agreed to participate were authorized.

\section{Sample Size}

The study sample size was 180 among which 90 are Health Science students (30 Malay, 30 Chinese and 30 Indians) and 90 are Non- Health Science students
(30 Malay, 30 Chinese and 30 Indians). Sample size was calculated based on the Krejzie and Morgan table.

\section{Inclusion and exclusion criteria}

The inclusion criteria include all Malaysian students aged 18-25 years old, of the three major races (Malay, Chinese and Indian) of both genders male and female and who were willing to provide written consent. The students under 18 and those above 25 or those not willing to participate and are not able to provide written consent were excluded from this study.

\section{Study survey instrument}

A self-administered validated questionnaire ${ }^{6}$ was used with the permission of the publishing author. The questionnaire collected the demographics of the participants and it also consists of five other different domains that gave us a clear idea. The questionnaire consists of 43 questions with a fixed response answering key. The questionnaire consists of 5 parts which are as follows, Part A is related to respondent's socio-demographic background (7 items), Part B relevant to knowledge regarding HIV/AIDS (5 statements), Part C on risk perception towards possible causes of HIV/AIDS (14 statements), Part $D$ on respondents' views about measure to prevent HIV transmissions (12 statements) and Part E on misconceptions towards HIV/AIDS (5 statements).

\section{Data Collection}

The self-administered questionnaire was distributed and collected from groups of students by the five investigators. The participants took approximately 5-10 minutes to fill up the questionnaire completely. The participants signed a consent form which included information about purpose, importance and procedure of the study.

\section{Statistical analysis plan}

All statistical analyses were performed using SPSS (version 23). Descriptive statistics were conducted to describe all the continuous (mean and standard deviation) and categorical variables (frequency distributions and percentages). The differences in the total mean score between the two groups (Health Science and Non-Health science) were compared using the Chi-square test. A two-tailed $p$ value of $<0.05$ was regarded as statistically significant.

\section{Ethical consideration}

The questionnaire was used with the consent of the author. Following clearance was obtained from 
members of Faculty of Medicine, SEGi University Kota Damansara. Brief explanation about the study was provided at the cover page of the questionnaires while instructions were stated clearly to the participants on how to fill it up. Written consent form was obtained from all the participants. They were informed that participation was voluntary. All information provided in questionnaire would be kept confidential and data will be used only for research purposes. Participants were reminded not to write their name and other personal identification numbers on the forms. All participants were free to withdraw from study at any time. Strict anonymity and confidentiality was maintained throughout the process of data collection and analysis.

\section{RESULTS}

The demographic characteristics of the total participants are presented in Table 1 . The evaluation was conducted with 180 students of both Health Science and Non-Health Science.

The mean age of the total participants was 21.23 years and its standard deviation is 1.695 years. Among the participants, 90 of them were Health Science students $(50 \%)$ and 90 of them were NonHealth Science students (50\%). The participants were composed of $53(29.4 \%)$ males and 127 (70.6\%) females. The participants were all Malaysians from the three major races in Malaysia (Malay $n=60$, Chinese $n=60$ and Indian $n=60$ ). The marital status of all participants is single. Among all the 180 participants, majority were Muslims 65 (36.1\%) followed by Buddhists 43 (23.9\%), Hindus 40 (22.2\%), Christians 28 (15.6\%) and others (2.2\%).

The frequency and percentage of correct answers and wrong answers among the participants based on faculty of the students were reported in Table 2.

The table showed that among the 5 questions regarding the general knowledge for HIV/AIDS, all the frequency and also the percentage of correct answers was higher in Health Science students (30.0\%-50.0\%) as compared to Non-Health Science students (20.0\%-45.0\%). In other words, the frequency and percentage of wrong answers was higher in Non-Health Science students (5.0\%-30.0\%) than in Health Science students (4.4\%-15.0\%). For example, the third variable, "Is AIDS a hereditary disease?", the frequency and percentage of correct answers for Health-Science students and NonHealth Science students were $65(35.0 \%)$ and 36 $(20.0 \%)$ respectively, while for the wrong answers were $27 \quad(15.0 \%)$ and 54 (30.0\%) respectively. Moreover, the $p$-value is 0 . It showed that there is a significant difference between the answers given by Health-Science students and also Non-Health Science students. For all the 5 questions of general knowledge about HIV/AIDS, there were significant difference shown in each question except for the fourth questions because its $p$-value is 0.079 which is greater than 0.05 , while for others are $0,0.018$, 0 and 0.009 .

Table 1: Demographic characteristics of the total participants $(n=180)$

\begin{tabular}{|c|c|c|c|}
\hline Characteristics & Total $(n=180)$ & $\begin{array}{l}\text { Health } \\
\text { Science }(n=90)\end{array}$ & $\begin{array}{l}\text { Non-Health } \\
(n=90)\end{array}$ \\
\hline Age $(y)$, mean $( \pm S D)$ & $21.23( \pm 1.695)$ & $21.18( \pm 1.481)$ & $21.08( \pm 1.892)$ \\
\hline \multicolumn{4}{|l|}{ Gender, n (\%) } \\
\hline Male & $53(29.4 \%)$ & $26(28.9 \%)$ & 27 (30.0\%) \\
\hline Female & $127(70.6 \%)$ & $64(71.1 \%)$ & $63(70.0 \%)$ \\
\hline \multicolumn{4}{|l|}{ Marital status } \\
\hline Single & $180(100 \%)$ & 90 (100\%) & 90 (100\%) \\
\hline \multicolumn{4}{|l|}{ Religion } \\
\hline Muslim & 65 (36.1\%) & 35 (38.9\%) & 30 (33.3\%) \\
\hline Christian & 28 (15.6\%) & 15 (16.7\%) & 13 (14.4\%) \\
\hline Buddhist & 43 (23.9\%) & 17 (18.9\%) & 26 (28.9\%) \\
\hline Hindu & 40 (22.2\%) & 21 (23.3\%) & 19 (21.1\%) \\
\hline Others & $4(2.2 \%)$ & $2(2.2 \%)$ & $2(2.2 \%)$ \\
\hline \multicolumn{4}{|l|}{ Race } \\
\hline Malay & 60 (33.3\%) & 30 (33.3\%) & 30 (33.3\%) \\
\hline Chinese & 60 (33.3\%) & 30 (33.3\%) & 30 (33.3\%) \\
\hline Indian & 60 (33.3\%) & 30 (33.3\%) & 30 (33.3\%) \\
\hline
\end{tabular}

SD denotes standard deviation, $n$ denotes number of participants, $y$ denotes years 
Table 2: Questions on general knowledge on HIV/AIDS $(n=180)$

\begin{tabular}{|c|c|c|c|c|c|}
\hline \multirow[t]{2}{*}{ Variables } & \multicolumn{2}{|l|}{ Correct Answers } & \multicolumn{2}{|c|}{ Wrong Answers } & \multirow[t]{2}{*}{$p$-value } \\
\hline & Health Science & $\begin{array}{l}\text { Non-Health } \\
\text { Science }\end{array}$ & $\begin{array}{l}\text { Health } \\
\text { Science }\end{array}$ & $\begin{array}{l}\text { Non-Health } \\
\text { Science }\end{array}$ & \\
\hline $\begin{array}{l}\text { General Knowledge } \\
\text { 1. AIDS abbreviation }\end{array}$ & $84(46.7 \%)$ & 57 (31.7\%) & $6(3.3 \%)$ & $33(18.3 \%)$ & 0.000 \\
\hline $\begin{array}{l}2 . \quad \text { AIDS a } \\
\text { transmittable disease }\end{array}$ & $85(47.2 \%)$ & 75 (41.7\%) & $5(2.8 \%)$ & $15(8.3 \%)$ & 0.018 \\
\hline $\begin{array}{l}\text { disease } \\
\text { 4. AIDS cured at this }\end{array}$ & $63(35.0 \%)$ & $36(20.0 \%)$ & 27 (15.0\%) & $54(30.0 \%)$ & 0.000 \\
\hline $\begin{array}{l}\text { moment } \\
5 \text {. There is a vaccine }\end{array}$ & $82(45.6 \%)$ & $74(41.1 \%)$ & $8(4.4 \%)$ & $16(8.9 \%)$ & 0.079 \\
\hline for AIDS Attitudes & $64(35.6 \%)$ & 47 (26.1\%) & $26(14.4 \%)$ & $43(23.9 \%)$ & 0.009 \\
\hline
\end{tabular}

Table 3 also shows the frequency and percentage of correct answers and wrong answers among the participants based on faculty of the students (Health Science and Non-Health Science). There are 14 questions related to the general public perception towards HIV/AIDS.
Majority of the data showed that Health Science students had a higher percentage (30.0\%-100.0\%) of correct answers when compared to Non-Health Science students (50.0\%-90.0\%). Out of 14 questions, there were 9 questions $(1,2,3,4,5,6,8$ ,11, 12) showing significant differences among the

Table 3: Questions related to the public perception $(n=180)$

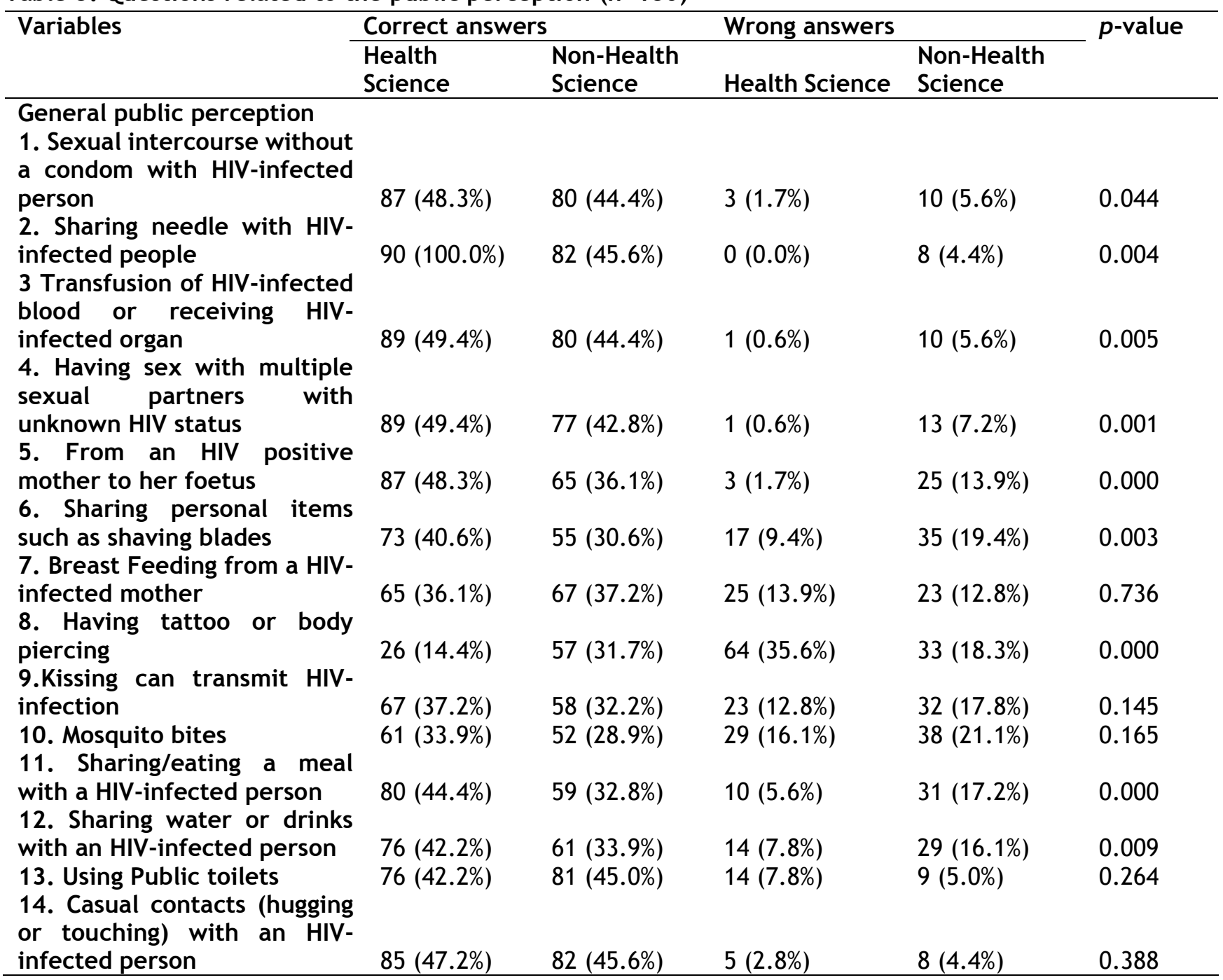


answers given by Health Science students and NonHealth Science students because the $p$-value for the 9 questions were $0.044,0.004,0.005,0.001,0$, $0.003,0,0$ and 0.009 respectively which is lower than 0.05 . However, the remaining 5 questions ( 7 , $9,10,13,14)$ did not show significant difference because their $p$-value were more than $0.05(0.736$, $0.145,0.165,0.264,0.388$ respectively).

In Table 4 below, the frequency and percentage of correct and wrong answers among the participants based on faculty of students were reported (Health Science and Non-Health Science Students). The table showed the 12 questions asking about the respondent's views about HIV/AIDS.

All the frequency and percentage of correct answers was higher in Health Science Students compared to Non-Health Science Students and vice versa for the wrong answers. Generally, the views of the both the groups (Health Science and Non-Health Science) were regarded as almost similar in comparison. For all the 12 questions of respondents views about HIV/AIDS, there was significant difference shown in each question except for the questions 1,6 and 12 because its respective $p$-value which are 0.136 , 0.193 and 0.122 are greater than 0.05 . In Table 5, the frequency and percentage of correct and wrong answers among the participants based on their faculties are reported (Health Science and NonHealth Science Students). The table showed 5 questions related to the misconceptions about HIV/AIDS.

The majority of Health Science respondents had less misconception about HIV/AIDS, with 75-85\% correctly answering the five statements. However, many misconceptions were still noted relating to HIV/AIDS, such as "AIDS is a punishment of God", "AIDS can be transmitted by cough" and "AIDS do not come after marriage" which at least of more than $10 \%$ of Non-Health Sciences Students had answered incorrectly. Furthermore, for the 5 questions on misconceptions about HIV/AIDS, there were significant differences shown in the questions 2 and 5 where the $p$-values were 0.005 and 0.26 respectively except for the questions 1,3 and 4 as the $p$-values were $0.264,0.388$ and 0.110 respectively.

Table 4: Questions about respondents' views about HIV/AIDS $(n=180)$

\begin{tabular}{|c|c|c|c|c|c|}
\hline \multirow[t]{2}{*}{ Variables } & \multicolumn{2}{|c|}{ Correct answers } & \multicolumn{2}{|c|}{ Wrong answers } & \multirow[t]{2}{*}{$p$-value } \\
\hline & $\begin{array}{l}\text { Health } \\
\text { Science }\end{array}$ & $\begin{array}{l}\text { Non-Health } \\
\text { Science }\end{array}$ & $\begin{array}{l}\text { Health } \\
\text { Science }\end{array}$ & $\begin{array}{l}\text { Non-Health } \\
\text { Science }\end{array}$ & \\
\hline \\
\hline $\begin{array}{l}\text { 1. Avoid taking illicit drugs/ use of } \\
\text { intravenous drugs } \\
\text { 2. Bv avoiding sharing needles and }\end{array}$ & $84(46.7 \%)$ & $78(43.3 \%)$ & $6(3.3 \%)$ & $12(6.7 \%)$ & 0.136 \\
\hline syringes & $89(49.4 \%)$ & $84(46.7 \%)$ & $1(0.6 \%)$ & $6(3.3 \%)$ & 0.054 \\
\hline $\begin{array}{l}\text { 3. Having sex with only one } \\
\text { faithful, uninfected partner }\end{array}$ & $89(49.4 \%)$ & $79(43.9 \%)$ & $1(0.6 \%)$ & $11(6.1 \%)$ & 0.003 \\
\hline intercourse & $88(48.9 \%)$ & $77(42.8 \%)$ & $2(1.1 \%)$ & $13(7.2 \%)$ & 0.003 \\
\hline $\begin{array}{l}\text { 5. Treating STDs promptly } \\
\text { 6. Screening donated blood }\end{array}$ & $87(48.3 \%)$ & $76(42.2 \%)$ & $3(1.7 \%)$ & $14(7.8 \%)$ & 0.005 \\
\hline $\begin{array}{l}\text { before transfusion } \\
\text { 7. Not sharing toilets with an }\end{array}$ & 87 (48.3\%) & $83(46.1 \%)$ & $3(1.7 \%)$ & $7(3.9 \%)$ & 0.193 \\
\hline $\begin{array}{l}\text { infected person } \\
8 \text {. Not sharing food with an }\end{array}$ & $73(40.6 \%)$ & $60(33.3 \%)$ & $17(9.4 \%)$ & $30(16.7 \%)$ & 0.027 \\
\hline $\begin{array}{l}\text { infected person } \\
\text { 9. Isolating people living with }\end{array}$ & $74(41.1 \%)$ & $56(31.1 \%)$ & $16(8.9 \%)$ & $34(18.9 \%)$ & 0.003 \\
\hline HIV/AIDS & $75(41.7 \%)$ & $52(28.9 \%)$ & $15(8.3 \%)$ & $38(21.1 \%)$ & 0.000 \\
\hline $\begin{array}{l}\text { person on same house } \\
\text { 11. Do not have casual contact }\end{array}$ & $81(45.0 \%)$ & $61(33.9 \%)$ & $9(5.0 \%)$ & $29(16.1 \%)$ & 0.000 \\
\hline $\begin{array}{l}\text { with infected person } \\
\text { 12. Avoid mosquito bites for HIV }\end{array}$ & $80(44.4 \%)$ & 67 (37.2\%) & $10(5.6 \%)$ & $23(12.8 \%)$ & 0.012 \\
\hline transmission & 62 (34.4\%) & $52(28.9 \%)$ & $28(15.6 \%)$ & $38(21.1 \%)$ & 0.122 \\
\hline
\end{tabular}


Table 5: Questions on misconceptions about HIV/AIDS $(n=180)$

\begin{tabular}{llllll}
\hline Variables & \multicolumn{2}{l}{ Correct answers } & \multicolumn{2}{l}{ Wrong answers } & p-value \\
\cline { 2 - 5 } & $\begin{array}{l}\text { Health } \\
\text { Science }\end{array}$ & $\begin{array}{l}\text { Non-Health } \\
\text { Science }\end{array}$ & $\begin{array}{l}\text { Health } \\
\text { Science }\end{array}$ & $\begin{array}{l}\text { Non-Health } \\
\text { Science }\end{array}$ & \\
\hline $\begin{array}{l}\text { Misconceptions } \\
\begin{array}{l}\text { 1. Love is a reason for } \\
\text { HIV/AIDS }\end{array}\end{array}$ & & & & \\
$\begin{array}{l}\text { 2. AIDS is a punishment of } \\
\text { God }\end{array}$ & $81(45.0 \%)$ & $76(42.2 \%)$ & $9(5.0 \%)$ & $14(7.8 \%)$ & 0.264 \\
$\begin{array}{l}\text { 3. AIDS can treat by holy } \\
\text { water }\end{array}$ & $85(44.4 \%)$ & $65(36.1 \%)$ & $10(5.6 \%)$ & $25(13.9 \%)$ & 0.005 \\
$\begin{array}{l}\text { 4. AIDS do not come after } \\
\text { marriage }\end{array}$ & $82(45.6 \%)$ & $5(2.8 \%)$ & $8(4.4 \%)$ & 0.388 \\
$\begin{array}{l}\text { 5. AIDS can be transmitted } \\
\text { by the cough }\end{array}$ & $81(43.9 \%)$ & $71(39.4 \%)$ & $11(6.1 \%)$ & $19(10.6 \%)$ & 0.110 \\
\hline
\end{tabular}

The majority of Health Science respondents had less misconception about HIV/AIDS, with 75-85\% correctly answering the five statements. However, many misconceptions were still noted relating to HIV/AIDS, such as "AIDS is a punishment of God", "AIDS can be transmitted by cough" and "AIDS do not come after marriage" which at least of more than $10 \%$ of Non-Health Sciences Students had answered incorrectly. Furthermore, for the 5 questions on misconceptions about HIV/AIDS, there were significant differences shown in the questions 2 and 5 where the $p$-values were 0.005 and 0.26 respectively except for the questions 1,3 and 4 as the $p$-values were $0.264,0.388$ and 0.110 respectively.

The Table 6 represented the mean and standard deviation of all the other tables (Table 2, 3, 4 and $5)$.

We found that the Health Science students generally had a higher percentage of correct answer with a mean and standard deviation of $44.31 \%$ and 0.015 respectively, whereas the Non-Health Science students had a higher percentage of wrong answers with a mean and standard deviation of $12.83 \%$ and 0.036 respectively.

Table 6: Total average of all variables $(n=180)$

\begin{tabular}{lllll}
\hline Variables & \multicolumn{2}{c}{ Correct answers } & Wrong answers \\
\cline { 2 - 5 } & Health Science & Non-Health Science & Health Science & Non-Health Science \\
\hline General Knowledge & $42.02 \%( \pm 0.062)$ & $32.12 \%( \pm 0.094)$ & $7.98 \%( \pm 0.062)$ & $17.88 \%( \pm 0.094)$ \\
General $\quad$ Public & & & & \\
Perception & $45.27 \%( \pm 0.182)$ & $37.94 \%( \pm 0.064)$ & $8.31 \%(0.095)$ & $12.06 \%( \pm 0.064)$ \\
Respondent Views & $44.85 \%( \pm 0.046)$ & $38.19 \%( \pm 0.067)$ & $5.15 \%( \pm 0.046)$ & $11.81 \%( \pm 0.067)$ \\
Misconceptions & $45.10 \%( \pm 0.013)$ & $40.44 \%( \pm 0.036)$ & $4.90 \%( \pm 0.013)$ & $9.56 \%( \pm 0.036)$ \\
Mean $( \pm S D)$ & $44.31 \%( \pm 0.015)$ & $37.17 \%( \pm 0.036)$ & $6.59 \%( \pm 0.018)$ & $12.83 \%( \pm 0.036)$ \\
\hline
\end{tabular}

SD denotes standard deviation

\section{DISCUSSION}

This is the first descriptive, cross-sectional study conducted to compare the knowledge and misconceptions of HIV/AIDS among the HealthScience students and Non-Health Science students in SEGi University, Kota Damansara. Since HIV is a very common infection, it is important that people should have ample knowledge and awareness about HIV/AIDS. This study could have a positive impact on raising awareness of HIV/AIDS knowledge and misconceptions among undergraduate students in Malaysian Universities. Educational awareness

programs about HIV/AIDS have been one of the key measures in controlling the infection, as they promote the healthy life style of the general public ${ }^{7}$. The study reveals several findings about the general knowledge, general public perceptions, respondent's views and misconceptions among Health Science students and also Non-Health Students in SEGi University. 


\section{General knowledge}

The respondents of both branches (Health Science students and Non-Health Science students) have a clear understanding about the abbreviation used for HIV/AIDS which was about $78 \%$ of the participants. The Health Science students (35\%-47\%) have more correct answer and thus have a better knowledge of HIV/AIDS than the Non-Health Science students (26\%-41\%). Based on the results on Table 4.2 , it shows a high percentage of correct answers of Health Science students (47.2\%) and Non-Health Science students $(41.7 \%)$ have knowledge on issues related to HIV/AIDS transmission. Both the groups had good knowledge about AIDS which cannot be cured having a high percentage (41\%-46\%) of correct answer.

Also, the notation that "AIDS is a hereditary disease" and "there is a vaccine for AIDS", the Health Science percentage of answering correctly was higher as compared to Non-Health Science percentage. In our study, however about $20 \%-35 \%$ of the respondents thought that AIDS is not a hereditary disease whereas about $26 \%-36 \%$ of the respondents thought there was no vaccine available for AIDS. Thus, overall the respondents had good knowledge about the abbreviation of AIDS, AIDS transmission and its curing except they lack knowledge of AIDS being a hereditary disease and whether there is a vaccine available for AIDS. A similar study was conducted in Tanzania; it spoke about three quarters of the respondents demonstrating comprehensive knowledge about HIV/AIDS ${ }^{8}$. In contrast, a study conducted in Saudi Arabia showed the overall mean knowledge score of the respondents was 5.2 correct answers out of 9 . However, in this study a low knowledge level of HIV/AIDS was found among the medical and nonmedical students 9 . Another study that was conducted among Sudanese University students stated that the participants had poor knowledge about HIV/AIDS ${ }^{10}$. Therefore, it is important to consider taking initiative in setting up various centres in order to instil a basic knowledge about the disease all around the world so that as to eliminate the stigma surrounding this disease.

\section{General public perceptions about HIV/AIDS}

For the questions regarding the general public's perception, many Health Science students in SEGi University had a wrong perception about having a tattoo or body piercing could transmit HIV/AIDS which is the same finding as the research done in urban African Americans in the South ${ }^{11}$.

From previous researches, ${ }^{12,13}$ it was found that most of the people were having misconceptions that "kissing could transmit HIV" which is the same with our research finding, $23(12.8 \%)$ students from
Health Science and $32(17.8 \%)$ students from NonHealth Science for the frequency and percentage for their wrong answer which was actually very high. Moreover, quite a number of Health Science students also had misconceptions about "breastfeeding from a HIV-infected mother could transmit the disease" and that "Mosquito bites could transmit HIV". These misconceptions were the same as the research which had been done in a Nigerian Teaching Hospital ${ }^{14}$. $59.5 \%$ of the study population in the research of Maimaiti $\mathrm{N}$ et al answered that HIV could be transmitted through mosquito bites. On the other hand, Non-Health Science students mostly had an incorrect perception about "Mosquito bites", "Sharing personal items such as shaving blades" and "Having tattoo and body piercing could transmit HIV." Through data analysis, there were three quarter of the questions showing significant difference between the answers given by Health Science students and Non-Health Science students. Students' perception about HIV/AIDS should be corrected because it is very important for them to prevent infection from HIV.

\section{Respondent views about preventive measures}

For this section, Health Science students had higher frequencies and also percentages of correct answers for all the 12 questions as compared to Non-Health Science students. The questions which Health Science students had very low frequency and percentages of correct answers were on the questions such as "Avoid mosquito bites for HIV transmission" (62 \& 34.4\%) and "Not sharing toilets with an infected person" (73 \& 40.6\%). In the previous research, there were $21.2 \%$ answers the question "Avoiding mosquito bites" correctly with is lower percentage than us. Moreover, another study carried in a public university in Malaysia showed that more than half of their participants $(77.4 \%)$ trusted that HIV infection could be transmitted through public toilet. This also proved that there were misconceptions among the students in public university of Malaysia ${ }^{15}$. In contrast, most of the Non-Health Science students got incorrect answers in questions like isolating people living with HIV/AIDS ( $52 \& 28, .9 \%$ ) and avoid mosquito bites for HIV transmission (52 \& 28.9\%). There were also same misconceptions happened as the research carried in Mahatma Gandhi Memorial and also researched carried out by Unal Ayranci in a Turkish population ${ }^{16}$. Overall, more than half of the Health Science students and Non-Health Science students answered the 12 questions correctly. This shows that most of the students in SEGi University have a correct mind set on preventive measures for HIV/AIDS.

\section{Misconceptions}

Misconception about HIV may cause a negative 
attitude towards people suffering from this serious disease that could lead to serious harm on their physical and emotional state. Misconception is a major barrier to control and prevent the spread of AIDS $^{17,18}$.

In a conservative country like Malaysia where it is not encouraged to talk about sexual issues, the expected rate of misconceptions was very high. This is also the same with other conservative countries like Sudan for example where it is rare for parents to discuss sensitive topics such as STDs with family members ${ }^{19}$. But our study revealed that most of the respondents didn't have a lot of misconceptions about HIV/AIDS. However, our findings showed that the Non-Health Science respondents had a higher percentage $(9.56 \%)$ of misconceptions than the Health Science respondents (4.90\%).

The statements that had the highest misconceptions from both populations were "AIDS is a punishment of God", "AIDS do not come after marriage" and "AIDS can be transmitted by the cough". Even though Malaysia is a religious country, for the statement "AIDS is a punishment of God" only few participants $10(5.6 \%)$ from Health Science and 25 (13.9\%) from Non-Health Science had incorrect answers. Other studies however, have shown that there was a higher percentage of people who believe that AIDS is a divine punishment from $\operatorname{God}^{7,12}$. Also comparing to a study done in Sudan for the statement "AIDS do not come after marriage", $11(6.1 \%)$ participants of Health Science and 19 (10.6\%) participants of Non-Health Science answered incorrectly. Finally, for the statement "AIDS can be transmitted by the cough", 9 (5.0\%) participants of health science and $20(11.1 \%)$ of nonhealth science answered incorrectly. A study conducted earlier in Japan showed that fear, lack of knowledge, or religious beliefs, negative attitudes towards HIV/AIDS patients can lead to stigmatization of the disease ${ }^{20}$. It is very important to take action in order to get rid of these misconceptions that people have towards HIV and AIDS. South Africa has set an interesting example in implementing HIV/AIDS prevention programs including community-based HIV awareness programs and education campaigns, research on HIV prevention together with the introduction of antiretroviral therapy (ART). This comprehensive approach has led to increased knowledge within the community which reduced the social stigma and led again to better uptake of voluntary counselling and HIV testing ${ }^{21}$. The Malaysian government could take up few of these above examples so as to create better awareness and knowledge among the population of the country.

\section{CONCLUSION}

This study draws a general picture of SEGi University student population's knowledge and misconceptions towards HIV/AIDS. Though the SEGi student population had a good knowledge background, there were few misconceptions that need to be addressed. Thus, this study was conducted to compare the knowledge and misconceptions among the two major branches (Health Science students and Non-Health Science students) in SEGi University, Kota Damansara. However, the major findings of this study were that the Health Science students had better knowledge and fewer misconceptions when compared to Non-Health Science students. Furthermore, from the study we come to a conclusion that despite the knowledge that the students possess it is important to raise awareness about this disease, and this can be done by taking the initiative in conducting campaigns, awareness programs, educational speeches, hosting fundraising events, produce information pamphlets and through social media awareness. It is equally important that both the study groups have adequate knowledge on this issue, but since the Non-Health Science students had a higher level of misconception and a low level of knowledge when compared to the Health Science, it is important to focus more on the Non-Health Science group.

\section{ACKNOWLEDGEMENT}

Special thanks to Dr. Ahmed Yusuf Y, Fathima Fahda, Periyanayagee Karuppan Chetty, Sakiba Tasnoor Fariha, Tanzida Shahjahan, Vincent Lau for their contribution to carry out this study.

\section{REFERENCES}

1. Baytner-Zamir R, Lorber $M$, Hermoni D. Assessment of the knowledge and attitudes regarding HIV/AIDS among pre-clinical medical students in Israel. BMC Res. Notes 2014; 7(1): 168.

2. Nubed CK, Akoachere J-FTK. Knowledge, attitudes and practices regarding HIV/AIDS among senior secondary school students in Fako Division, South West Region, Cameroon. BMC Public Health 2016; 16(1): 847.

3. Khawcharoenporn T, Chunloy K, Apisarnthanarak A. Uptake of HIV testing and counseling, risk perception and linkage to HIV care among Thai university students. BMC Public Health 2016; 16(1): 556.

4. Wong L-P, Chin C-KL, Low $W-Y$, et al. HIV/AIDS-related knowledge among Malaysian young adults: Findings from a 
nationwide survey. J Int AIDS Soc 2008; 10(6): 148.

5. Nazmul MHM, Farzana Y, Deepthi S, et al. General knowledge and misconceptions about HIV/AIDS among the university students in Malaysia. Indian J Public Health Res Dev 2018; 9(10): 435-440.

6. Akshaya $S$ Bhagavathula et al. A cross sectional study: the knowledge, attitude, perception, misconception and views (KAPMV) of adult family members of people living with human immune virus-HIV acquired immune deficiency syndrome-AIDS (PLWHA) Springer Plus 2015; 4:769 DOI 10.1186/s40064-015-1541-2.

7. Janahi EM, Mustafa S, Alsari S, et al. Public knowledge, perceptions, and attitudes towards HIV/AIDS in Bahrain: A crosssectional study. J Infect Dev Ctries 2016; 10(09): 1003-1011.

8. Mkumbo K, Assessment of HIV/AIDS knowledge, attitudes and behaviours among students in higher education in Tanzania. Glob Public Health 2013; 8(10): 1168-1179.

9. Alwafi HA, Meer AM, Shabkah A, et al. Knowledge and attitudes toward HIV/AIDS among the general population of Jeddah, Saudi Arabia. J Infect Public Health 2018; 11(1): 80-84.

10. Elbadawi A, Mirghani H. Assessment of HIV/AIDS comprehensive correct knowledge among Sudanese university: a crosssectional analytic study 2014. Pan Afr. Med. J. 2016; 24(1).

11. Klein H, Sterk C, Elifson K. Knowledge about HIV in a community sample of urban African Americans in the South. J. AIDS Clin. Res. 2016; 7(10).

12. Bhagavathula AS, Bandari DK, Elnour AA, et al. A cross sectional study: the knowledge, attitude, perception, misconception and views (KAPMV) of adult family members of people living with human immune virus-HIV acquired immune deficiency syndrome-AIDS
(PLWHA). SpringerPlus 2015; 4(1): 769.

13. Yazdi C, Aschbacher K, Arvantaj A, et al. Knowledge, attitudes and sources of information regarding HIV/AIDS in Iranian adolescents. AIDS Care 2006; 18(8): 10041010.

14. Opeodu O, Ogunrinde T. Mode of transmission of HIV/Aids: Perception of dental patients in a nigerian teaching hospital. J West Afr Coll Surg 2015; 5(1): 1.

15. Soleymani S, Rahman HA, Lekhraj R, et al. A cross-sectional study to explore postgraduate students' understanding of and beliefs about sexual and reproductive health in a public university, Malaysia. Reprod Health 2015; 12(1): 77.

16. Ayranci U. AIDS knowledge and attitudes in a Turkish population: an epidemiological study. BMC Public Health 2005; 5(1): 95.

17. Corrigan PW, Penn DL. Lessons from social psychology on discrediting psychiatric stigma. Am. Psychol. 1999; 54(9): 765.

18. Lieber $E$, Li L, Wu $Z$, et al. HIV/STD stigmatization fears as health-seeking barriers in China. AIDS Behav. 2006; 10(5): 463-471.

19. Karim QA, Meyer-Weitz A, Harrison A. Interventions with youth in high-prevalence areas, in HIV Prevention: Elsevier 2009: 407443.

20. Wang G, Wada K, Hoshi K, et al. Association of knowledge of HIV and other factors with individuals' attitudes toward HIV infection: a national cross-sectional survey among the Japanese non-medical working population. PLoS One 2013; 8(7): e68495.

21. Mall S, Middelkoop K, Mark D, et al. Changing patterns in HIV/AIDS stigma and uptake of voluntary counselling and testing services: the results of two consecutive community surveys conducted in the Western Cape, South Africa. AIDS Care 2013; 25(2):194-201. 